\title{
OPEN In vitro response of vanilla (Vanilla planifolia Jacks. ex Andrews) to PEG-induced osmotic stress
}

\author{
Eduardo Martínez-Santos ${ }^{1}$, Carlos Alberto Cruz-Cruz ${ }^{2}$, José Luis Spinoso-Castillo ${ }^{1} \&$ \\ Jericó Jabín Bello-Bello ${ }^{3 \times}$
}

Drought-induced water stress affects the productivity of the Vanilla planifolia Jacks. ex Andrews crop. In vitro culture technique is an effective tool for the study of water stress tolerance mechanisms. This study aimed to evaluate the morphological, physiological and biochemical response of $V$. planifolia under in vitro water stress conditions induced with polyethylene glycol (PEG). In vitro regenerated shoots of $2 \mathrm{~cm}$ in length were subjected to different concentrations of PEG $6000(0,1,2$ and $3 \%$ $\mathrm{w} / \mathrm{v}$ ) using Murashige and Skoog semi-solid culture medium. At 60 days of culture, different growth variables, dry matter (DM) content, chlorophyll (Chl), soluble proteins (SP), proline (Pro), glycine betaine (GB), stomatal index (SI) and open stomata (\%) were evaluated. Results showed a reduction in growth, Chl content, SP, SI and open stomata (\%) with increasing PEG concentration, whereas DM, Pro and GB contents rose with increasing PEG concentration. In conclusion, PEG-induced osmotic stress allowed describing physiological and biochemical mechanisms of response to water stress. Furthermore, the determination of compatible Pro and GB osmolytes can be used as biochemical markers in future breeding programs for the early selection of water stress tolerant genotypes.

Vanilla (Vanilla planifolia Jacks. ex Andrews) is an orchid species native to Mexico used for the extraction of vanillin, one of the most economically important aromatic compounds worldwide ${ }^{1}$. This species, which has a hemiepiphytic habit, requires water and abundant moisture for proper development ${ }^{2}$. It is estimated that one of the main factors affecting vanilla production is its high susceptibility to pests and diseases and its low tolerance to water stress conditions, due to its low genetic variability ${ }^{3}$. In addition, various climate change scenarios forecast prolonged droughts that will cause water stress in plants ${ }^{4}$. Vanilla is also categorized as endangered B2ab(iii, v) version 3.1 in the International Union for Conservation of Nature and Natural Resources (IUCN) red list of threatened plants (http://www.iucnredlist.org).

In plants, the main water stress tolerance mechanisms are the accumulation of reactive oxygen species, synthesis of antioxidant enzymes, synthesis of specific proteins (hydrophilins, dehydrins, chaperonins) and osmotic adjustment mediated by compatible osmolytes ${ }^{5-8}$. Water stress reduces the availability of water in the cytoplasm of cells, affecting their homeostasis. Lack of water in cells causes osmotic and oxidative stress, damaging physiological, biochemical and molecular processes ${ }^{5,9}$.

In vitro osmotic stress simulation using osmotic agents is an efficient technique that provides a controlled and uniform environment for the study of different water stress response mechanisms ${ }^{10}$. High molecular weight polyethylene glycol (PEG) is highly soluble in water and non-penetrable in cells, produces a negative osmotic potential in the culture medium without generating toxicity and is one of the most widely used osmotic agents to study the effects of in vitro water stress in plants ${ }^{11}$. The use of PEG as an in vitro stress agent has been evaluated in crops such as sugar beet (Beta vulgaris L.) $)^{12}$, nopal (Opuntia ficus-indica (L.) Mill) ${ }^{13}$, wheat (Triticum durum Desf. $)^{14}$, stevia (Stevia rebaudiana Bert.) ${ }^{15,16}$, and banana (Musa acuminata Colla) ${ }^{17,18}$ among others. In the family Orchidaceae, it has been used in Acianthera teres Lindl., Octomeria crassifolia Lindl., O. gracilis Barb. Rodr. $^{19}$, Prosthechea vitellina W. E. Higgins ${ }^{20}$ and Dendrobium officinale Kimura and Migo ${ }^{21}$. In Vanilla genus there is limited information on the response to osmotic stress under in vitro conditions and the mechanisms of response to water stress in $V$. planifolia have not been fully studied. The objective of this study was to evaluate the morphological, physiological and biochemical responses in in vitro $V$. planifolia shoots under water stress conditions induced by PEG.

${ }^{1}$ Colegio de Postgraduados Campus Córdoba, Carretera Córdoba Veracruz, Amatlán de los Reyes Km 348, 94946 Veracruz, Mexico. ${ }^{2}$ Universidad Veracruzana-Facultad de Ciencias Químicas, Oriente 6, No. 1009, Orizaba, 94340 Veracruz, Mexico. ${ }^{3}$ CONACYT-Colegio de Postgraduados Campus Córdoba, Carretera Córdoba Veracruz, Amatlán de los Reyes Km 348, 94946 Veracruz, Mexico. ${ }^{\circledR}$ email: jericobello@gmail.com 


\begin{tabular}{|l|l|l|l|l|l|l|l|l|}
\hline PEG (\%) & $\begin{array}{l}\text { Osmotic potential } \\
(\mathbf{M p a})\end{array}$ & Shoot length $(\mathbf{m m})$ & Number of leaves & Number of roots & Root length $(\mathbf{m m})$ & Fresh weight (mg) & Dry weight (mg) & Dry matter (\%) \\
\hline 0 & -0.14 & $67.60 \pm 3.05^{\mathrm{a}}$ & $5.70 \pm 0.30^{\mathrm{a}}$ & $5.80 \pm 0.20^{\mathrm{a}}$ & $31.00 \pm 1.59^{\mathrm{a}}$ & $2.51 \pm 0.61^{\mathrm{a}}$ & $0.20 \pm 0.04^{\mathrm{a}}$ & $7.97 \pm 0.22^{\mathrm{b}}$ \\
\hline 1 & -0.23 & $37.40 \pm 2.0 \mathrm{~s}^{\mathrm{b}}$ & $3.10 \pm 0.23^{\mathrm{b}}$ & $4.20 \pm 0.33^{\mathrm{b}}$ & $24.20 \pm 2.55^{\mathrm{b}}$ & $1.00 \pm 0.14^{\mathrm{ab}}$ & $0.10 \pm 0.01^{\mathrm{ab}}$ & $10.01 \pm 0.61^{\mathrm{a}}$ \\
\hline 2 & -0.32 & $41.00 \pm 3.07^{\mathrm{b}}$ & $3.00 \pm 0.26^{\mathrm{b}}$ & $4.70 \pm 0.37^{\mathrm{b}}$ & $18.90 \pm 1.21^{\mathrm{b}}$ & $1.02 \pm 0.32^{\mathrm{ab}}$ & $0.11 \pm 0.03^{\mathrm{ab}}$ & $10.79 \pm 0.69^{\mathrm{a}}$ \\
\hline 3 & -0.43 & $26.60 \pm 0.81^{\mathrm{c}}$ & $2.00 \pm 0.21^{\mathrm{c}}$ & $2.60 \pm 0.22^{\mathrm{c}}$ & $11.10 \pm 0.64^{\mathrm{c}}$ & $0.44 \pm 0.06^{\mathrm{b}}$ & $0.05 \pm 0.00^{\mathrm{b}}$ & $11.37 \pm 0.97^{\mathrm{a}}$ \\
\hline
\end{tabular}

Table 1. Effect of different PEG 6000 concentrations on the in vitro growth of Vanilla planifolia. Values represent the mean \pm SE (standard error) at 60 days of culture. Means with different letters are significantly different (Tukey, $p \leq 0.05$ ).

\section{Results}

PEG-induced osmotic stress. The osmotic potential ( $\Psi$ s $)$ of the culture medium rose as PEG concentrations increased, obtaining values of $\Psi \mathrm{s}=-0.14,-0.23,-0.32$ and $-0.43 \mathrm{MPa}$ for $0,1,2$ and $3 \%$ PEG, respectively. When evaluating the effect of different PEG concentrations on the in vitro growth of $V$. planifolia, significant differences were observed in shoot length, number of leaves, number and length of roots and percentage of dry matter (Table 1).

Overall, in vitro growth of $V$. planifolia decreased with increasing PEG concentrations. The longest shoots $(67.6 \mathrm{~mm})$ were obtained at $0 \%$ of PEG, whereas the shortest shoots $(26.6 \mathrm{~mm})$ were obtained with $3 \%$ of PEG. For the variable number of leaves per shoot, the highest number of leaves (5.7) was observed in $0 \%$ of PEG, while the lowest number of leaves (2.0) was observed in 3\% of PEG. For the variables number and length of roots, the shoots with the highest number (5.8) and length of roots $(31.0 \mathrm{~mm})$ were observed in $0 \%$ of PEG, while the smallest number $(2.6)$ and size of roots $(11.1 \mathrm{~mm}$ ) was found in the treatment with $3 \%$ of PEG (Fig. 1). For fresh weight and dry weight, the only significant decrease $(0.44 \mathrm{mg})$ and $(0.05 \mathrm{mg})$ in comparison with control was recorded in 3\% of PEG, respectively. Regarding dry matter content, the highest percentages $(10.01,10.79$ and $11.37 \%$ ) were observed in the PEG treatments, while the lowest percentage $(7.97 \%)$ was observed in the control treatment.

Chlorophyll (Chl) content. Significant differences were observed in Chl contents in leaves of V. planifolia seedlings exposed to different concentrations of PEG 6000. The highest total Chl $\left(0.45 \mathrm{mg} \mathrm{g}^{-1} \mathrm{FW}\right)$ and Chl a $\left(0.32 \mathrm{mg} \mathrm{g}^{-1} \mathrm{FW}\right)$ contents were observed in the $0 \%$ of PEG treatment, followed by the 1,2 and $3 \%$ of PEG treatments, respectively. The highest $\mathrm{Chl} \mathrm{b}$ contents $\left(0.14\right.$ and $\left.0.12 \mathrm{mg} \mathrm{g}^{-1} \mathrm{FW}\right)$ were observed in the 0 and $1 \%$ PEG treatments, while lower Chl b contents $\left(0.10\right.$ and $\left.0.08 \mathrm{mg} \mathrm{g}^{-1} \mathrm{FW}\right)$ were observed in the 2 and $3 \%$ PEG treatments (Figure 2a).

Soluble protein (SP) content. Differences in SP content were observed at all PEG concentrations. The highest SP content $\left(23 \mathrm{mg} \mathrm{g}^{-1} \mathrm{FW}\right)$ was observed in the $1 \%$ of PEG treatment, while lower SP contents were observed (17, 14 and $3 \mathrm{mg} \mathrm{g}^{-1} \mathrm{FW}$ ) in the 2,3 and $0 \%$ of PEG treatments, respectively (Fig. 2b).

Proline (Pro) content. A gradual increase in Pro content was observed with increasing PEG concentration. The highest Pro content $\left(2.7 \mu \mathrm{mol} \mathrm{g}{ }^{-1} \mathrm{FW}\right)$ was observed at $3 \%$ of PEG, while the lowest contents $(1.2,1.0$ and $0.08 \mu \mathrm{mol} \mathrm{g}{ }^{-1} \mathrm{FW}$ ) were observed in the 2,1 and $0 \%$ of PEG treatments, respectively (Fig. 2c).

Glycine betaine (GB) content. A gradual increase in GB content was observed with increasing PEG concentration. The highest GB content $\left(28 \mu \mathrm{mol} \mathrm{g}^{-1} \mathrm{DW}\right)$ was observed at $3 \%$ of PEG, while the lowest contents $(15$, 12 and $4 \mu \mathrm{mol} \mathrm{g}^{-1} \mathrm{DW}$ ) were observed in the 2,1 and $0 \%$ of PEG treatments, respectively (Fig. $2 \mathrm{~d}$ ).

Stomatal index (SI) and percentage of open stomata. Significant differences were observed in the SI and percentage of open stomata of $V$. planifolia exposed to different PEG concentrations. The highest SI (4.8) was observed in the control treatment, followed by the 1,2 and 3\% of PEG treatments, respectively (Fig. 3). The highest percentage of open stomata $(92 \%)$ was observed in the control treatment, followed by the PEG treatments (Fig. 4).

\section{Discussion}

Results obtained in this study demonstrate that in vitro growth of $V$. planifolia is affected under osmotic stress conditions induced by different PEG concentrations. The different PEG concentrations had an effect on the osmotic potential of the culture medium ( $\Psi$ s $=-0.14,-0.23,-0.32$ and $-0.43 \mathrm{MPa}$ for $0,1,2$ and $3 \%$ of PEG). The PEG 6000-induced osmotic stress affects the in vitro growth of V. planifolia. One of the most important strategies that plants have adopted against osmotic stress is to stop or slow their growth ${ }^{22,23}$. In fact, slow growth is an adaptive response for plant survival under stress conditions ${ }^{24}$.

Bello-Bello et al. ${ }^{25}$ reported that, during in vitro preservation of $V$. planifolia using $3 \%$ PEG 6000, this osmotic agent acts as a growth inhibitor. Similar results were described by Gao et al. ${ }^{21}$ who found significant differences in the growth of Dendrobium officinale shoots with 1, 3 and 5\% of PEG 6000. Jácome-Blásquez et al. ${ }^{20}$ reported a reduction in germination of Prosthechea vitellina (Lindl.) W. E. Higgins with an increasing concentration of 

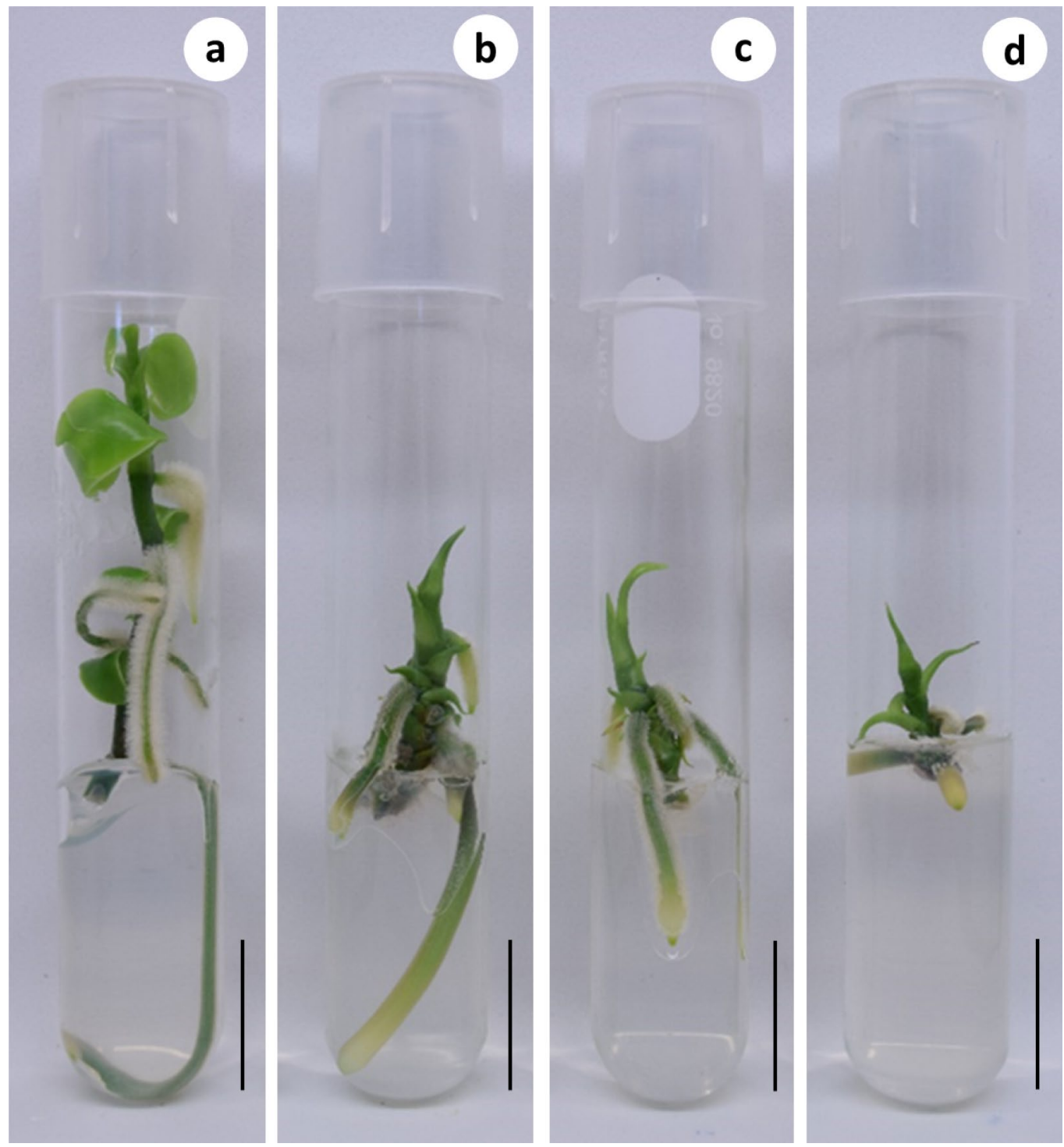

Figure 1. Effect of different concentrations of PEG 6000 on the growth of Vanilla planifolia at 60 days of culture. (a-d) 0,1,2 and 3\% PEG 6000, respectively. Black bar $=2 \mathrm{~cm}$.

PEG 8000. Ramírez-Mosqueda et al. ${ }^{26}$ obtained the lowest number of leaves and roots per explant in Laelia anceps Lindl. with 3\% of PEG 8000. Piwowarczyk et al. ${ }^{27}$ reported an increased dry matter content in shoots of eight genotypes of grass pea (Lathyrus sativus) with 5, 10 and $15 \%$ of PEG 6000. According to Rai et al. ${ }^{28}$, growth inhibition under water stress is associated with a reduction in the ability of plants to absorb water and nutrients caused by the decreased water potential of the culture medium.

In this study, the inhibition of in vitro V. planifolia shoot growth in the presence of PEG could be explained by the synthesis of phytohormones responsible of stomatal closure, causing a reduction in transpiration and low carbon assimilation capacity. According to the authors of Ref. ${ }^{29}$, the stomatal closure under drought condition is due to the accumulation of compounds such as abscisic acid, methyl jasmonate, ethylene, and brassinosteroids. On the other hand, the increase in dry matter content in the presence of PEG could be explained by synthesis of specific proteins, compatible osmolytes and/or metabolites in response to water stress and probably due to accumulation of inorganic solutes in relation to osmotic adjustment.

In this study, a decrease in total Chl content was observed in V.planifolia shoots in relation to the increase in PEG concentration. In Orchidaceae in vitro, Gao et al. ${ }^{21}$ reported a decrease in Chl content in D. officinale shoots exposed to $0,1,3$ and 5\% of PEG 6000. Suis et al..$^{30}$ found a reduction in Chl content in protocorm-like bodies of Aranda Broga Blue Bell with 15\% of PEG 400. A reduction in Chl content in V. planifolia under water stress $(-0.9 \mathrm{MPa})$ has been reported under ex vitro conditions ${ }^{31}$. For chlorophyll content, according to the authors of Ref. ${ }^{32}$, a reduced chlorophyll content under water stress is caused by a decrease in photosynthetic activity due to stomatal closure. Also, the low photosynthetic activity is related to dry matter accumulation as a result of osmotic stress affecting carbohydrate transport ${ }^{33,34}$. In addition, with low photosynthetic activity, Chl degradation is a response mechanism to avoid energy wasting ${ }^{35-37}$. 

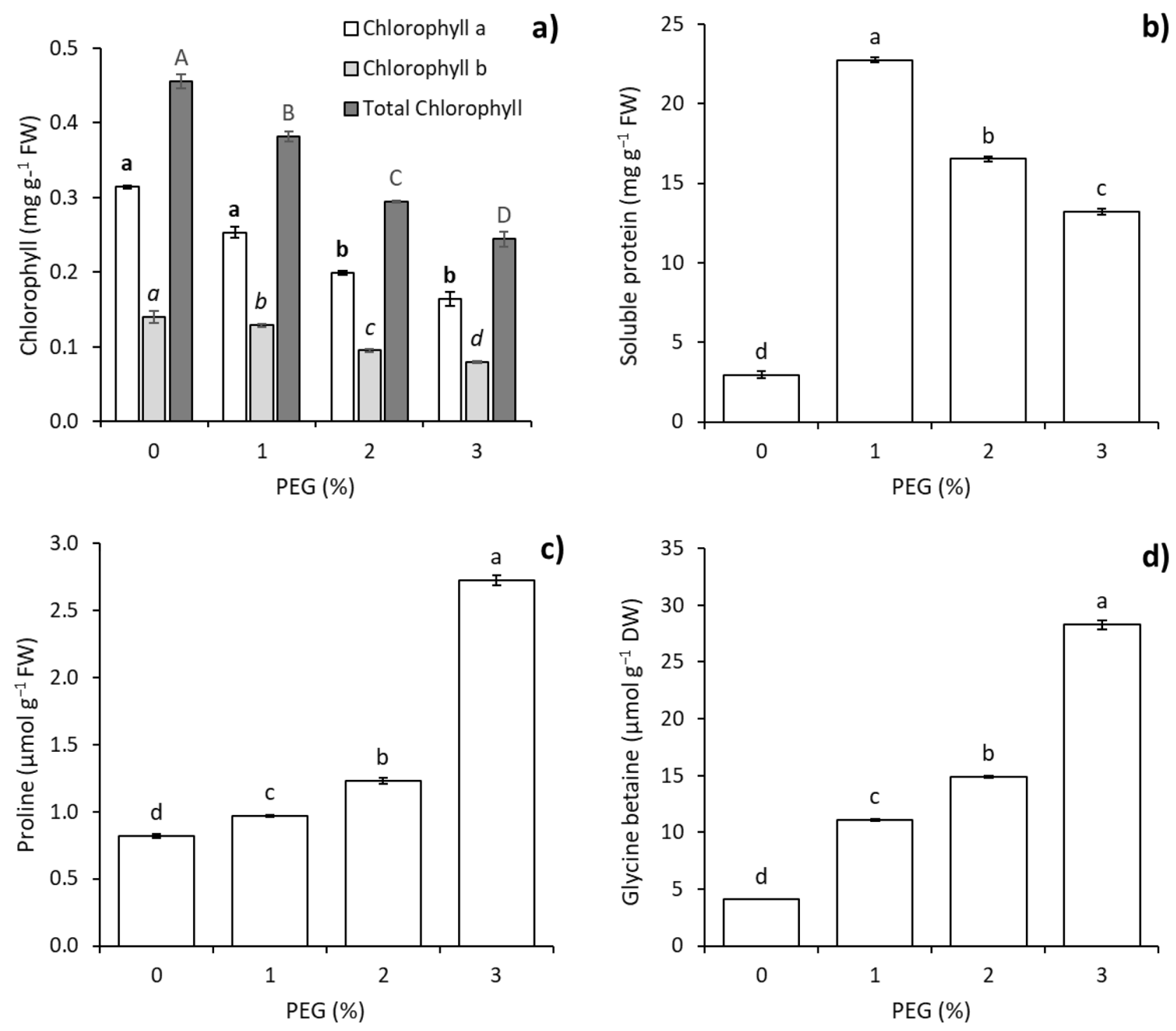

Figure 2. Effect of PEG 6000 on biochemical responses of in vitro Vanilla planifolia shoots at 60 days of culture. (a) Chlorophyll contents, (b) soluble protein, (c) proline and (d) glycine betaine. Values represent the mean $\pm \mathrm{SE}$ (standard error). Means with different letters are significantly different (Tukey, $\mathrm{p} \leq 0.05$ ).

Results of biochemical analysis showed significant differences in SP, Pro and GB contents (Fig. 2). The SP content decreased with increasing PEG concentration in V. planifolia shoots; however, SP content was significantly higher in all PEG treatments with respect to the control treatment. Variation in SP content is a water stress tolerance response ${ }^{37}$ related to synthesis, accumulation or degradation. The SP accumulation at $1 \%$ of PEG compared to control (without PEG stress) is probably related to the synthesis of hydrophilins ${ }^{38}$, aquaporins ${ }^{39}$, dehydrins $s^{40}$, antioxidant enzymes ${ }^{41}$, and chaperonins ${ }^{42}$, among others. Plants can synthesize this type of protein to neutralize oxidative stress and osmotic stress ${ }^{41,43}$. The SP reduction in 2 and $3 \%$ of PEG could be explained due to a degradation and/or synthesis reduction caused by a physiological wilting point in plants during in vitro osmotic stress.

Qayyum et al. ${ }^{44}$ reported an increase in protein content in seedlings of five wheat (Tritricum aestivum L.) cultivars exposed to different osmotic potentials $(-0.2,-0.4$ and $-0.6 \mathrm{MPa})$ generated with PEG 6000. In contrast, Razavizadeh et al. ${ }^{35}$ observed a decrease in protein content in thyme (Thymus vulgaris) seedlings grown under 2, 4, 6 and $8 \%$ of PEG 6000. Similarly, Gao et al. ${ }^{21}$ observed a decrease in protein content in D. officinale shoots grown under water stress induced with 1,3 and $5 \%$ of PEG 6000 . Suis et al. ${ }^{30}$ observed a reduction in SP using PEG 400 (0, 5, 10 and 15\%) in protocorm-like bodies of the Aranda Broga Blue Bell orchid. Chandran and Puthur ${ }^{31}$ note that the decrease in SP content in the V4 somaclone of V. planifolia under water stress $(-0.9$ $\mathrm{MPa}$ ) may be due to its degradation.

The results of this study suggest that under the in vitro conditions evaluated, protein accumulation in $1 \%$ of PEG treatments could be explained by the biosynthesis of specific proteins as a mechanism of tolerance to osmotic stress; whereas, the decrease in SP content at doses of 2 and $3 \%$ of PEG could be due to a reduction in biosynthesis and/or an increase in their degradation. Razavizadeh et al. ${ }^{35}$ note that protein degradation under osmotic stress provides sources of nitrogen used in different metabolic processes. 


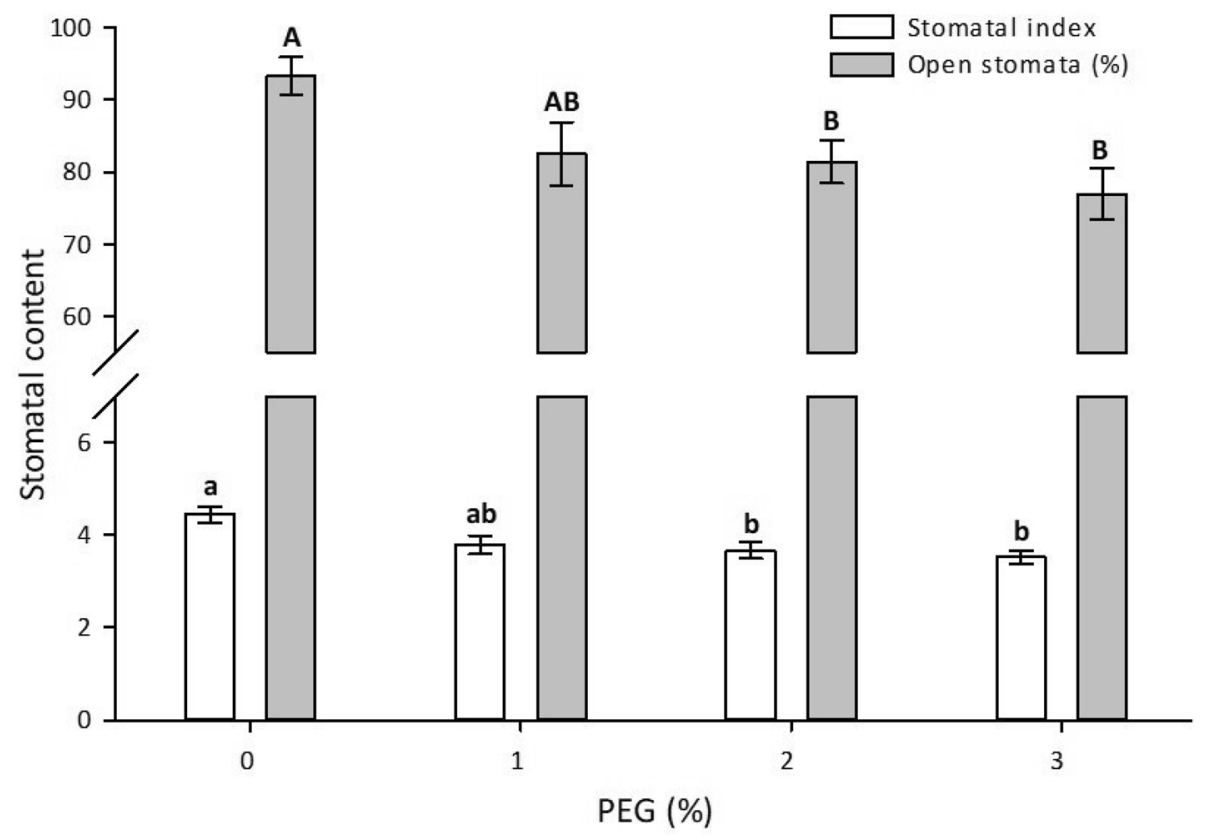

Figure 3. Effect of PEG 6000 on the stomatal content of in vitro Vanilla planifolia shoots at 60 days of culture. Values represent the mean \pm SE (standard error). Means with different letters are significantly different (Tukey, $\mathrm{p} \leq 0.05)$.

The Pro accumulation in plants is a physiological response to salt and water stress by reducing plant growth ${ }^{45}$. Under water stress conditions, Pro acts as a stabilizer of structural proteins, a compatible osmolyte and a catalyst of antioxidant enzyme activity ${ }^{46}$. In our study, a significant increase in Pro content was observed in shoots exposed to PEG; however, the 3\% PEG treatment showed a twofold increase in Pro content compared to the control. This result suggest that Pro has a role in water stress tolerance mechanisms in $V$. planifolia.

Other studies show that Pro is a biochemical indicator that contributes to water stress tolerance mechanisms. Piwowarczyk et al. ${ }^{27}$ reported an increase in Pro content in grass pea (Lathyrus sativus) shoots at 5, 10 and $15 \%$ of PEG 6000. Razavizadeh et al. ${ }^{35}$ observed an increase in Pro accumulation in thyme (Thymus vulgaris) shoots at 2, 4, 6 and $8 \%$ of PEG. In Orchidaceae, Jácome-Blásquez et al. ${ }^{20}$ found that the Pro content in Prosthechea vitellina (Lindl.) W. E. Higgins increased by twice as much relative to the control treatment by increasing the PEG 8000 concentration. In contrast, a previous study reported ${ }^{21}$ that the Pro content in Dendrobium officinale shoots decreased in the treatments with 1, 3 and 5\% of PEG 6000. In addition to Pro, there are other osmolytes such as sugars and GB that accumulate in response to water stress ${ }^{47}$.

Glycine betaine content showed a significant increase when $V$. planifolia shoots were exposed to PEG. To date, GB accumulation in V. planifolia under in vitro water stress has not been reported. However, GB accumulation has been reported in other species. Hajihashemi and Ehsanpour ${ }^{48}$ reported GB accumulation in S. rebaudiana shoots exposed to 2, 4 and 6\% of PEG 6000. Datir and Inamdar ${ }^{49}$ observed that GB accumulation increased in all wheat (T. aestivum L.) cultivars in response to water stress induced by $15 \%$ of PEG 6000 . Jácome-Blásquez et al. ${ }^{20}$ found increased GB content in P. vitellina (Lindl.) W. E. Higgins at 5-15\% of PEG 8000 . In addition, GB is a compatible osmolyte that acts as an osmoprotectant, maintains photosynthetic activity by protecting the thylakoid membrane, and neutralizes reactive oxygen species by regulating the expression of oxidative stress response genes during osmotic stress ${ }^{37,50-52}$. The absence of GB in cells could result in cell membrane damage, protein degradation, DNA damage and loss of photosynthetic capacity ${ }^{37,53,54}$.

PEG-induced osmotic stress reduced the SI and percentage of open stomata in V. planifolia. Paletri et al. ${ }^{55}$ reported a decrease in SI in Cattleya sp. Lindl. in vitro with $25 \%$ of PEG 6000. Chandran and Puthur ${ }^{31}$ reported a reduced SI (1.65) in ex vitro somaclones of $V$. planifolia under water stress generated by water deficit $(-0.9 \mathrm{MPa})$. According to the authors of Ref. ${ }^{56}$, variation in the SI under water stress is different for each species. V. planifolia under normal conditions has a SI of $2.81 \pm 0.27^{31}$. On the other hand, stomatal closure as a result of using PEG for the evaluation of osmotic stress in vitro has been reported. Another study ${ }^{57}$ found a reduction in stomatal opening in Persian walnut (Juglans regia L.) of 43 and 58\% at 3 and 5\% of PEG 6000 relative to the control.

Plant stomata are normally open during in vitro conditions due to excess water in culture medium and high humidity within the culture vessels. However, the stomatal functionality is stimulated during in vitro PEGinduced osmotic stress. Stomatal functionality, through the opening and closing of stomata, is a mechanism that regulates transpiration and maintains water balance during hydric stress ${ }^{58}$. In this regard, it has been reported ${ }^{59}$ that adequate stomatal functionality regulates the water balance in plants. Stomatal closure and a low SI generate a low transpiration rate to avoid dehydration due to water loss. 

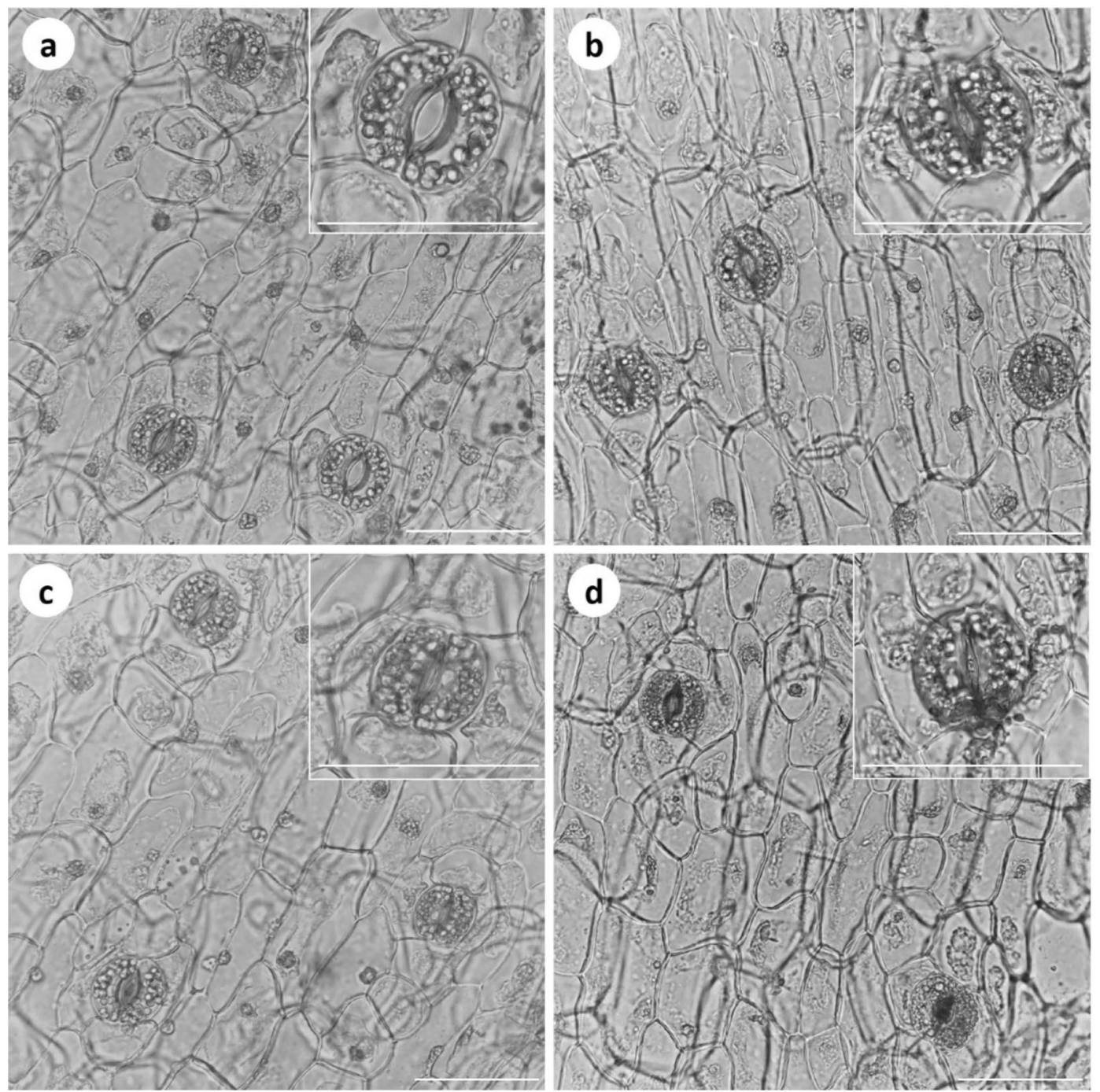

Figure 4. Effect of different PEG 6000 concentrations on the stomatal index and open stomata of Vanilla planifolia. (a-d) 0, 1, 2 and 3\% PEG 6000, respectively. White bar $=2.5 \mu \mathrm{m}$.

\begin{abstract}
Methods
Plant material selection and in vitro establishment. Vanilla planifolia Jacks. ex Andrews has been listed in the IUCN due to its highly fragmented populations. For sampling and in vitro propagation of plant material, an appropriate permission was granted by the National Agro-Alimentary Health, Safety and Quality Service (SENASICA, certificate No. LAB 30044001/2018) and the authorization approved by land or facilities that manage wildlife (No. SGPA/DGVS/2868/19). All procedures performed in the study were in compliance with the IUCN Policy Statement on Research Involving Species at Risk of Extinction and the Convention on the Trade in Endangered Species of Wild Fauna and Flora. For in vitro establishment, young V. planifolia cuttings with 7-8 buds were collected from a commercial plantation located in the community of El Palmar, Emiliano Zapata, Veracruz, Mexico (19 $39^{\prime} 86^{\prime \prime} \mathrm{N}$ and $\left.-96^{\circ} 75^{\prime} 17^{\prime \prime} \mathrm{W}\right)$. Cuttings were kept in quarantine under greenhouse conditions at an irradiance of $130 \mu \mathrm{mol} \mathrm{m}^{-2} \mathrm{~s}^{-1}, 30 \pm 2{ }^{\circ} \mathrm{C}$, and $60 \pm 5 \%$ relative humidity, in potting soil (peatmoss and agrolite, 1:1) with weekly applications of $0.1 \%(\mathrm{w} / \mathrm{v})$ fungicidal solution (Cupravit, Bayer AG, Leverkusen, NW, DEU) and 0.1\% (w/v) bactericidal solution (Agrimycin, Pfizer, New York, NY, USA). After 40 days, 3-5 cm long nodal segments were collected. The nodes were transferred to the laboratory where they were washed with Axion commercial detergent (Mission Hills, S.A. de C.V., San José de Iturbide, GT, MEX) and tap water; subsequently, they were reduced to $2 \mathrm{~cm}$ in length and immersed in a soap solution with two drops of Tween 20 (Sigma-Aldrich Chemical Company, St. Louis, MO, USA) per $100 \mathrm{~mL}$ for $5 \mathrm{~min}$ followed by five rinses with distilled water. In a laminar flow hood, the explants were immersed in a $15 \%(\mathrm{v} / \mathrm{v})$ solution of commercial $\mathrm{NaClO}$ (5\% AI, Clorox, Monterrey, NL, MEX) solution and three rinses were performed with sterile distilled water. Subsequently, the explants were immersed in a $0.1 \%(\mathrm{w} / \mathrm{v})$ of mercuric chloride $\left(\mathrm{HgCl}_{2}\right)$ solution and three rinses were performed with sterile distilled water. Finally, the disinfected explants were individually transferred to $500 \mathrm{~mL}$ flasks containing $30 \mathrm{~mL}$ of $\mathrm{MS}^{60}$ multiplication medium supplemented with $30 \mathrm{~g} \mathrm{~L}^{-1}$ sucrose, $2 \mathrm{mg} \mathrm{L}^{-1}$
\end{abstract}


6-Benzylaminopurine (BAP) (Sigma-Aldrich) and $2.3 \mathrm{~g} \mathrm{~L}^{-1}$ Phytagel (Sigma-Aldrich) as a gelling agent. The $\mathrm{pH}$ of the medium was adjusted to 5.8 and autoclaved for $15 \mathrm{~min}$ at $121^{\circ} \mathrm{C}$ and $117.7 \mathrm{kPa}$. All cultures were incubated at $24 \pm 2{ }^{\circ} \mathrm{C}$ with a $16 \mathrm{~h}$ photoperiod with fluorescent lamps at an irradiance of $50 \mu \mathrm{mol} \mathrm{m}^{-2} \mathrm{~s}^{-1}$.

Osmotic stress induction with PEG. For in vitro selection pressure with PEG, $2 \mathrm{~cm}$ long shoots (without roots) obtained after four subcultures of 45 days each in multiplication medium were used. The shoots were grown in $22 \times 150 \mathrm{~mm}$ test tubes containing $20 \mathrm{~mL}$ of MS semi-solid medium without growth regulators and different concentrations of PEG $6000 \mathrm{MW}$ (Sigma-Aldrich) (0, 1, 2 and 3\% w/v). The PEG was added directly into the culture medium. The culture medium $\mathrm{pH}$ and the sterilization and incubation conditions were the same as described above. Each treatment consisted of 10 explants, with one shoot per test tube. At 60 days of culture (without explant subcultures), the different morphological variables and percentage of dry matter (DM) were evaluated. The DM content was calculated using the formula: dry weight/fresh weight $\times 100$. Chl, SP, Pro and GB contents were determined. Additionally, SI and percentage of open stomata were evaluated.

Osmotic potential measurements of the culture medium. The osmotic potential ( $\Psi$ s) of the semisolid culture media with different PEG concentrations was determined using a vapor pressure osmometer (5520 Vapro, Wescor Inc., Logan, UT, USA) at the beginning of osmotic stress induction.

Determination of chlorophyll (Chl) content. The Chl content was determined according to the methodology proposed by Ref. ${ }^{61}$ and with slight modifications by Ref. ${ }^{62}$. The absorbance readings were measured in a spectrophotometer (Genesys 10S, Thermo Scientific, Waltham, MA, USA) at $663 \mathrm{~nm}$ and 645 for Chl a and b, respectively. The $\mathrm{Chl}$ content was calculated using the following formulas:

$$
\begin{aligned}
& \text { Chlorophyll a }(\mathrm{C})=\left(\left[\left(12.7 \times \mathrm{A}_{663}\right)-\left(2.59 \times \mathrm{A}_{645}\right)\right](\mathrm{V})\right) /(1000 \times \mathrm{W}), \\
& \text { Chlorophyll b }(\mathrm{C})=\left(\left[\left(22.9 \times \mathrm{A}_{645}\right)-\left(4.70 \times \mathrm{A}_{663}\right)\right](\mathrm{V})\right) /(1000 \times \mathrm{W}), \\
& \text { Total Chl }(\mathrm{C})=\left(\left[\left(8.20 \times \mathrm{A}_{663}\right)-\left(20.2 \times \mathrm{A}_{645}\right)\right](\mathrm{V})\right) /(1000 \times \mathrm{W})
\end{aligned}
$$

where $\mathrm{A}_{663}$ and $\mathrm{A}_{645}$ : Absorbance; $\mathrm{C}$ : Concentration $\left(\mathrm{mg} \mathrm{g}^{-1} \mathrm{FW}\right)$; $\mathrm{V}$ : volume graduation in $\mathrm{mL}^{-1}$; W: sample weight in $\mathrm{g}$; 1000: conversion factor.

Determination of soluble protein (SP) content. Soluble protein estimation was carried out with the colorimetric method proposed by Bradford ${ }^{63}$. First, $100 \mathrm{mg}$ of fresh leaf tissue were weighed and macerated in a mortar in $25 \mathrm{~mL}$ of cold acetone for $5 \mathrm{~s}$. The macerated tissue was vacuum filtered and $12.5 \mathrm{~mL}$ of acetone was added. Then $5 \mathrm{~mL}$ of $0.1 \mathrm{M}$ TRIS-HCl Buffer ( $\mathrm{pH} 7.1$ ) was added to the extract obtained and the samples were stored on ice bath. Subsequently, they were centrifuged at $3100 \times \mathrm{g}$ for $20 \mathrm{~min}$ at $4^{\circ} \mathrm{C}$. A $100 \mu \mathrm{L}$ aliquot of the supernatant was acquired and added to $4.9 \mathrm{~mL}$ of Bradford reagent. After $12 \mathrm{~min}$ of reaction, the chromophore was read at an absorbance of $595 \mathrm{~nm}$ in a spectrophotometer (Genesys 10S). Quantification was done using a calibration curve with bovine albumin standard (Hoffmann-La Roche Ltd., Grenzacherstrasse, BS, SWI).

Determination of proline (Pro) content. Proline determination was carried out by the method described by Ref. ${ }^{64}$. First, $125 \mathrm{mg}$ of fresh leaf tissue were macerated in a mortar and homogenized with $5 \mathrm{~mL}$ of $3 \%(\mathrm{w} / \mathrm{v})$ sulfosalicylic acid. The resulting solution was filtered through Whatman \#2 filter paper. Then 1 $\mathrm{mL}$ aliquot was acquired, $1 \mathrm{~mL}$ of glacial acetic acid and $1 \mathrm{~mL}$ of ninhydrin were added. Incubation of $1 \mathrm{~mL}$ of the extract was carried out in a thermoregulated bath for one hour at $100{ }^{\circ} \mathrm{C}$. The tubes were removed and the reaction terminated in an ice bath. Then $2 \mathrm{~mL}$ of toluene was added and mixed for $30 \mathrm{~s}$ for phase separation. The resulting chromophore was read at an absorbance of $520 \mathrm{~nm}$ in the spectrophotometer (Genesys 10S) using toluene as a blank. Quantification was done using a calibration curve with L-proline standard (Sigma-Aldrich).

Determination of glycine betaine (GB) content. Glycine betaine determination was carried out by the method proposed by Ref. ${ }^{65}$. For this, $100 \mathrm{mg}$ of dry leaf tissue were weighed and reacted with water and $2 \mathrm{~N}$ $\mathrm{H}_{2} \mathrm{SO}_{4}$ after the addition of $0.2 \mathrm{~mL}$ of periodide complex $\left(\mathrm{KI}-\mathrm{I}_{2}\right)$. Extraction was performed by centrifugation at $3100 \times g$ for $20 \mathrm{~min}$ at $4{ }^{\circ} \mathrm{C}$ and subsequent addition of $9 \mathrm{~mL}$ of 1,2-Dichloroethane. Absorbance was measured at $365 \mathrm{~nm}$ in a spectrophotometer (Genesys 10S) using 1,2-Dichloroethane as a blank. Quantification was done using a calibration curve with betaine standard (Sigma-Aldrich).

Stomatal index (SI) and percentage of open stomata. The SI and the percentage of open stomata were measured on the underside of the third leaf in relation to the shoot apex. The SI was determined by the formula: $\mathrm{SI}=$ [number of stomata/(number of epidermal cells + number of stomata) $] \times 100$. To visualize the stomata and epidermal cells per $\mathrm{mm}^{2}$, leaf samples were examined under a microscope (Axio Lab.A1, Carl Zeiss AG, Jena, TH, DEU). The percentage of open stomata was calculated using the total number of stomata and the number of open stomata.

Experimental design and statistical analysis. All experiments were conducted with a completely randomized design and replicated three times $(3 \times 10)$, with a total of 30 explants in each treatment. The data 
obtained were tested with an analysis of variance (ANOVA) followed by Tukey's test ( $p \leq 0.05)$, performed using IBM SPSS statistical software version 22 (https://www.ibm.com/support/pages/node/313621).

\section{Conclusions}

Polyethylene glycol induced osmotic stress under in vitro conditions had effects on growth, physiology and biochemical determinations evaluated in V. planifolia. In this study, a reduction in growth, chlorophyll content, soluble proteins, stomatal index and open stomata (\%) was observed with increasing PEG concentration, whereas dry matter, proline and glycine betaine contents rose with increasing PEG concentration. The compatible proline and glycine betaine osmolytes will be helpful mechanism of water stress tolerance in $V$. planifolia genotypes. In addition, ROS production and antioxidant enzyme activities could be evaluated in a future study for a better understanding of water stress tolerance. Further research is recommended to study others species in Vanilla genus in these in vitro conditions.

Received: 10 April 2021; Accepted: 11 November 2021

Published online: 19 November 2021

\section{References}

1. Arya, S. S., Rookes, J. E., Cahill, D. M. \& Lenka, S. K. Vanillin: A review on the therapeutic prospects of a popular flavouring molecule. Adv. Tradit. Med. https://doi.org/10.1007/s13596-020-00531-w (2021).

2. Castro-Bobadilla, G., Martínez, A. J., Martínez, M. L. \& y García-Franco, J. G. Aplicación de riego localizado para aumentar la retención de frutos de Vanilla planifolia en el Totonacapan, Veracruz, México. Agrociencia 45(3), 281-291 (2011).

3. Li, J., Demesyeux, L., Brym, M. \& Chambers, A. H. Development of species-specific molecular markers in Vanilla for seedling selection of hybrids. Mol. Biol. Rep. 47(3), 1905-1920. https://doi.org/10.1007/s11033-020-05287-9 (2020).

4. Monterroso-Rivas, A. I. \& y Gómez-Díaz, J. D. Impacto del cambio climático en la evapotranspiración potencial y periodo de crecimiento en México. Terra LatAm. 39, 1-19. https://doi.org/10.28940/terra.v39i0.774 (2021).

5. Vinocur, B. \& Altman, A. Recent advances in engineering plant tolerance to abiotic stress: Achievements and limitations. Curr. Opin. Biotechnol. 16(2), 123-132. https://doi.org/10.1016/j.copbio.2005.02.001 (2005).

6. Siddiqui, M. H. et al. Response of different genotypes of faba bean plant to drought stress. Int. J. Mol. Sci. 16, 10214-10227. https:// doi.org/10.3390/ijms160510214 (2015).

7. Siddiqui, M. H., Khan, M. N., Mohammad, F. \& Khan, M. M. A. Role of nitrogen and gibberellin (GA3) in the regulation of enzyme activities and in osmoprotectant accumulation in Brassica juncea L. under salt stress. J. Agron. Crop Sci. 194, 214. https://doi.org/ 10.1111/j.1439-037X.2008.00308.x (2008).

8. Hanif, S. et al. Biochemically triggered heat and drought stress tolerance in rice by proline application. J. Plant Growth Regul. 40, 305-312. https://doi.org/10.1007/s00344-020-10095-3 (2021).

9. Ahanger, M. A., Gul, F., Ahmad, P. \& Akram, N. A. Environmental stresses and metabolomics-Deciphering the role of stress responsive metabolites. In Plant Metabolites and Regulation Under Environmental Stress (eds Ahmad, P. et al.) 53-67 (Academic Press, 2018).

10. Nikam, A. A. et al. Radiation-induced in vitro mutagenesis system for salt tolerance and other agronomic characters in sugarcane (Saccharum officinarum L.). Crop J. 3, 46-56. https://doi.org/10.1016/j.cj.2014.09.002 (2015).

11. Zivcak, M., Brestic, M. \& Sytar, O. Osmotic adjustment and plant adaptation to drought stress. In Drought Stress Tolerance in Plants (eds Hossain, M. et al.) 105-143 (Springer, 2016).

12. Sen, A. \& Alikamanoglu, S. Analysis of drought-tolerant sugar beet (Beta vulgaris L.) mutants induced with gamma radiation using SDS-PAGE and ISSR markers. Mutat. Res. Fund. Mol. Mater. 738, 38-44. https://doi.org/10.1016/j.mrfmmm.2012.08.003 (2012).

13. Mengesha, B., Mekbib, F. \& Abraha, E. In vitro screening of cactus [Opuntia ficus-indicia (L) Mill] genotypes for drought tolerance. Am. J. Plant Sci. 7(13), 1741. https://doi.org/10.4236/ajps.2016.713163 (2016).

14. Kacem, N. S., Delporte, F., Muhovski, Y., Djekoun, A. \& Watillon, B. In vitro screening of durum wheat against waterstress mediated through polyethylene glycol. J. Genet. Eng. Biotechnol. 15, 239-247. https://doi.org/10.1016/j.jgeb.2017.04.004 (2017).

15. Pradhan, N., Singh, P., Dwivedi, P. \& Pandey, D. K. Evaluation of sodium nitroprusside and putrescine on polyethylene glycol induced drought stress in Stevia rebaudiana Bertoni under in vitro condition. Ind. Crop. Prod. 154, 112754. https://doi.org/10. 1016/j.indcrop.2020.112754 (2020).

16. Thakur, K., Sood, A., Kumar, P., Kumar, D. \& Warghat, A. R. Steviol glycoside accumulation and expression profiling of biosynthetic pathway genes in elicited in vitro cultures of Stevia rebaudiana. In Vitro Cell. Dev. Biol. Plant. https://doi.org/10.1007/s11627-02010151-3 (2021).

17. El-Mahdy, M. T., Abdel-Wahab, D. A. \& Youssef, M. In vitro morpho-physiological performance and DNA stability of banana under cadmium and drought stresses. In Vitro Cell. Dev. Biol. Plant. https://doi.org/10.1007/s11627-020-10142-4 (2021).

18. Mohd Amnan, M. A. et al. Osmotic stress in banana is relieved by exogenous nitric oxide. PeerJ 9, e10879. https://doi.org/10.7717/ peerj.10879 (2021).

19. Barbero, A. P. P., Barros, F. D., Silva, E. A. D. \& e Suzuki, R. M. Influência do déficit hídrico na germinação de sementes e no desenvolvimento inicial de três espécies de Pleurothallidinae (Orchidaceae). Braz. J. Bot. 34(4), 593-601. https://doi.org/10.1590/ S0100-84042011000400012 (2011).

20. Jácome-Blásquez, F., Morales-Ramos, V., Martínez-Hernández, M. D. J., Sanchez-Viveros, G. \& Bello-Bello, J. J. Response to peginduced hydric stress on in vitro germination of Prosthechea vitellina (Lindl.) WE Higgins (Orchidaceae). Propag. Ornam. Plants 16(3), 73-78 (2016).

21. Gao, H., Xu, D., Zhang, H., Cheng, X. \& Yang, Q. Effects of culture medium composition and PEG on hyperhydricity in Dendrobium officinale. In Vitro Cell. Dev. Biol. Plant https://doi.org/10.1007/s11627-020-10075-y (2020).

22. Queiros, F., Fidalgo, F., Santos, I. \& Salema, R. In vitro selection of salt tolerant cell lines in Solanum tuberosum L.. Biol. Plant 51(4), 728-734. https://doi.org/10.1007/s10535-007-0149-y (2007).

23. Darvishani, S. N. H., Chamani, E., Omran, V. O. G., Esmaeilpour, B. \& Yaghoubian, Y. In-vitro physiochemical responses of Viola odorata plant to combined salt and drought stress. Acta Sci. Pol. Hortoru. 19(4), 53-62. https://doi.org/10.24326/asphc.2020.4.5 (2020).

24. Rao, K., Raghavendra, A. \& Reddy, K. Physiology and Molecular Biology of Stress Tolerance in Plants 15-40 (Springer, 2006).

25. Bello-Bello, J. J., García-García, G. G. \& e Iglesias-Andreu, L. Conservación de vainilla (Vanilla planifolia Jacks.) bajo condiciones de lento crecimiento in vitro. Rev. Fitotec. Mex. 38(2), 165-171. https://doi.org/10.35196/rfm.2015.2.165 (2015).

26. Ramírez-Mosqueda, M. A., Cruz-Cruz, C. A., Atlahua-Temoxtle, J. \& Bello-Bello, J. J. In vitro conservation and regeneration of Laelia anceps Lindl.. S. Afr. J. Bot. 121, 219-223. https://doi.org/10.1016/j.sajb.2018.11.010 (2019).

27. Piwowarczyk, B., Kamińska, I. \& Rybiński, W. Influence of PEG generated osmotic stress on shoot regeneration and some biochemical parameters in Lathyrus culture. Czech J. Genet. Plant 50(2), 77-83. https://doi.org/10.17221/110/2013-CJGPB (2014). 
28. Rai, M. K., Kalia, R. K., Singh, R., Gangola, M. P. \& Dhawan, A. K. Developing stress tolerant plants through in vitro selection-An overview of the recent progress. Environ. Exp. Bot. 71(1), 89-98. https://doi.org/10.1016/j.envexpbot.2010.10.021 (2011).

29. Agurla, S., Gahir, S., Munemasa, S., Murata, Y. \& Raghavendra, A. S. Mechanism of stomatal closure in plants exposed to drought and cold stress. In Survival Strategies in Extreme Cold and Desiccation. Advances in Experimental Medicine and Biology Vol. 1081 (eds Iwaya-Inoue, M. et al.) (Springer, 2018).

30. Suis, M. A. F., Ping, K. S., Keong, C. C. \& Subramaniam, S. Biochemical and physiological responses to polyethylene glycol (PEG) treatment in protocorm-like bodies (PLBs) of Aranda Broga Blue Bell. Emir. J. Food Agric. https://doi.org/10.9755/ejfa.2015-04-080 (2015).

31. Chandran, S. \& Puthur, J. T. Assorted response of mutated variants of Vanilla planifolia Andr. towards drought. Acta Physiol. Plant 31(5), 1023-1029. https://doi.org/10.1007/s11738-009-0321-4 (2009).

32. Hussain, H. A. et al. Chilling and drought stresses in crop plants: Implications, cross talk, and potential management opportunities. Front. Plant Sci. 9, 1-21. https://doi.org/10.3389/fpls.2018.00393 (2018).

33. Tokarz, B., Wójtowicz, T., Makowski, W., Jedrzejczyk, R. J. \& Tokarz, K. M. What is the Difference between the response of grass pea (Lathyrus sativus L.) to salinity and drought stress? - A physiological study. Agronomy 10(6), 1-24. https://doi.org/10.3390/ agronomy10060833 (2020).

34. Hu, S., Ding, Y. \& Zhu, C. Sensitivity and responses of chloroplasts to heat stress in plants. Front. Plant Sci. 11, 1-11. https://doi. org/10.3389/fpls.2020.00375 (2020).

35. Razavizadeh, R., Farahzadianpoor, F., Adabavazeh, F. \& Komatsu, S. Physiological and morphological analyses of Thymus vulgaris L. in vitro cultures under polyethylene glycol (PEG)-induced osmotic stress. In Vitro Cell. Dev. Biol. Plant 55(3), 342-357. https:// doi.org/10.1007/s11627-019-09979-1 (2019).

36. Miglani, G. S., Kaur, R., Sharma, P. \& Gupta, N. Leveraging photosynthetic efficiency toward improving crop yields. J. Crop Improv. https://doi.org/10.1080/15427528.2020.1824168 (2020).

37. Ilyas, M. et al. Drought tolerance strategies in plants: A mechanistic approach. J. Plant Growth Regul. https://doi.org/10.1007/ s00344-020-10174-5 (2020).

38. Battaglia, M., Olvera-Carrillo, Y., Garciarrubio, A., Campos, F. \& Covarrubias, A. A. The enigmatic LEA proteins and other hydrophilins. Plant Physiol. 148, 6-24. https://doi.org/10.1104/pp.108.120725 (2008).

39. Hussain, S. S., Iqbal, M. T., Arif, M. A. \& Amjad, M. Beyond osmolytes and transcription factors: Drought tolerance in plants via protective proteins and aquaporins. Biol. Plant 55, 401-413. https://doi.org/10.1007/s10535-011-0104-9 (2011).

40. Chiappetta, A. et al. A dehydrin gene isolated from feral olive enhances drought tolerance in Arabidopsis transgenic plants. Front. Plant Sci. 6, 392. https://doi.org/10.3389/fpls.2015.00392 (2015).

41. Sewelam, N., Kazan, K. \& Schenk, P. M. Global plant stress signaling: Reactive oxygen species at the cross-road. Front. Plant Sci. 7, 187. https://doi.org/10.3389/fpls.2016.00187 (2016).

42. Zia, R., Nawaz, M. S., Siddique, M. J., Hakim, S. \& Imran, A. Plant survival under drought stress: Implications, adaptive responses, and integrated rhizosphere management strategy for stress mitigation. Microbiol. Res. https://doi.org/10.1016/j.micres.2020.126626 (2020).

43. Li, X., Tang, Q., Tang, H. \& Chen, W. Identifying antioxidant proteins by combining multiple methods. Front. Bioeng. Biotechnol. 8, 858. https://doi.org/10.3389/fbioe.2020.00858 (2020).

44. Qayyum, A. et al. Water stress effects on biochemical traits and antioxidant activities of wheat (Triticum aestivum L.) under in vitro conditions. Acta Agric. Scand. B 68, 283-290. https://doi.org/10.1080/09064710.2017.1395064 (2018).

45. Forlani, G., Trovato, M., Funck, D. \& Signorelli, S. Regulation of proline accumulation and its molecular and physiological functions in stress defence. In Osmoprotectant-Mediated Abiotic Stress Tolerance in Plants 1st edn (eds Hossain, M. A. et al.) 73-97 (Springer, 2019).

46. Kaur, G. \& Asthir, B. Proline: A key player in plant abiotic stress tolerance. Biol. Plant 59(4), 609-619. https://doi.org/10.1007/ s10535-015-0549-3 (2015).

47. Seleiman, M. F. et al. Drought stress impacts on plants and different approaches to alleviate its adverse effects. Plants 10(2), 259. https://doi.org/10.3390/plants10020259 (2021).

48. Hajihashemi, S. \& Ehsanpour, A. A. Influence of exogenously applied paclobutrazol on some physiological traits and growth of Stevia rebaudiana under in vitro drought stress. Biología 68(3), 414-420. https://doi.org/10.2478/s11756-013-0165-7 (2013).

49. Datir, S. S. \& Inamdar, A. Biochemical responses of wheat cultivars to PEG-induced drought stress. Russ. Agric. Sci. 45(1), 5-12. https://doi.org/10.3103/S1068367419010038 (2019).

50. Yang, X., Liang, Z., Wen, X. \& Lu, C. Genetic engineering of the biosynthesis of glycinebetaine leads to increased tolerance of photosynthesis to salt stress in transgenic tobacco plants. Plant Mol. Biol. 66(1-2), 73. https://doi.org/10.1007/s11103-007-9253-9 (2008).

51. Chen, T. H. \& Murata, N. Glycinebetaine protects plants against abiotic stress: Mechanisms and biotechnological applications. Plant Cell Environ. 34(1), 1-20. https://doi.org/10.1111/j.1365-3040.2010.02232.x (2011).

52. Zhang, X. et al. Mechanisms of glycine betaine enhancing oxidative stress tolerance and biocontrol efficacy of Pichia caribbica against blue mold on apples. Biol. Control 108, 55-63. https://doi.org/10.1016/j.biocontrol.2017.02.011 (2017).

53. Giri, J. Glycinebetaine and abiotic stress tolerance in plants. Plant Signal. Behav. 6(11), 1746-1751. https://doi.org/10.4161/psb.6. 11.17801 (2011).

54. Kumar, V. et al. Glycinebetaine-mediated abiotic oxidative-stress tolerance in plants: Physiological and biochemical mechanisms. In Stress Signaling in Plants: Genomics and Proteomics Perspective 1st edn (eds Sarwat, M. et al.) 111-133 (Springer, 2017).

55. Paletri, T. S., Nurcahyani, E., Yulianty, Y. \& Agustrina, R. Stomata index of Cattleya sp. Lindl., planlet in drought-stress conditions. J. BEKH 6(1), 15-19 (2019).

56. Pirasteh-Anosheh, H., Saed-Moucheshi, A., Pakniyat, H. \& Pessarakli, M. Stomatal responses to drought stress. In Water Stress and Crop Plants: A Sustainable Approach (ed. Ahmad, P.) 24-40 (Wiley, 2016).

57. Aliniaeifard, S., Asayesh, Z. M., Driver, J. \& Vahdati, K. Stomatal features and desiccation responses of Persian walnut leaf as caused by in vitro stimuli aimed at stomatal closure. Trees 34, 1219-1232. https://doi.org/10.1007/s00468-020-01992-x (2020).

58. Farooq, M., Wahid, A., Kobayashi, N., Fujita, D. \& Basra, S. M. A. Plant drought stress: Effects, mechanisms and management. In Sustainable Agriculture 1st edn (eds Lichtfouse, E. et al.) 153-188 (Springer, 2009).

59. Souza, T. C. et al. Morphophysiology, morphoanatomy, and grain yield under field conditions for two maize hybrids with contrasting response to drought stress. Acta Physiol. Plant 35(11), 3201-3211. https://doi.org/10.1007/s11738-013-1355-1 (2013).

60. Murashige, T. \& Skoog, F. A revised medium for rapid growth and bio assays with tobacco tissue cultures. Physiol. Plant. 15(3), 473-497. https://doi.org/10.1111/j.1399-3054.1962.tb08052.x (1962).

61. Harborne, J. B. Nitrogen compounds. In Phytochemical Methods (ed. Harborne, J. B.) 166-211 (Springer, 1973).

62. Martínez-Estrada, E., Islas-Luna, B., Pérez-Sato, J. A. \& Bello-Bello, J. J. Temporary immersion improves in vitro multiplication and acclimatization of Anthurium andreanum Lind.. Sci. Hortic. 249, 185-191. https://doi.org/10.1016/j.scienta.2019.01.053 (2019).

63. Bradford, M. M. A rapid and sensitive method for the quantitation of microgram quantities of protein utilizing the principle of protein-dye binding. Anal. Biochem. 72(1-2), 248-254. https://doi.org/10.1016/0003-2697(76)90527-3 (1976).

64. Bates, L. S., Waldren, R. P. \& Teare, I. D. Rapid determination of free proline for water-stress studies. Plant Soil 39(1), 205-207. https://doi.org/10.1007/BF00018060 (1973). 
65. Grieve, C. M. \& Grattan, S. R. Rapid assay for determination of water soluble quaternary ammonium compounds. Plant Soil 70(2), 303-307. https://doi.org/10.1007/BF02374789 (1983).

\section{Author contributions}

S.E.M.-S. and J.J.B.-B. designed the experiments, analyzed the data, conducted data interpretation and drafted the manuscript, S.E.M.-S. conducted all the experimental work, C.A.C.-C., J.L.S.-C. and J.J.B.-B. contributed to the conceptualization of the experiment and revising the manuscript. All authors reviewed the manuscript.

\section{Competing interests}

The authors declare no competing interests.

\section{Additional information}

Correspondence and requests for materials should be addressed to J.J.B.-B.

Reprints and permissions information is available at www.nature.com/reprints.

Publisher's note Springer Nature remains neutral with regard to jurisdictional claims in published maps and institutional affiliations.

Open Access This article is licensed under a Creative Commons Attribution 4.0 International License, which permits use, sharing, adaptation, distribution and reproduction in any medium or format, as long as you give appropriate credit to the original author(s) and the source, provide a link to the Creative Commons licence, and indicate if changes were made. The images or other third party material in this article are included in the article's Creative Commons licence, unless indicated otherwise in a credit line to the material. If material is not included in the article's Creative Commons licence and your intended use is not permitted by statutory regulation or exceeds the permitted use, you will need to obtain permission directly from the copyright holder. To view a copy of this licence, visit http://creativecommons.org/licenses/by/4.0/.

(C) The Author(s) 2021 